\title{
Impact of Consumer Locus of Control and Involvement on Socially and Ecologically Conscious Consumer Behaviour
}

\author{
Meghna Kaparwan \\ University School of Management Studies, Guru Gobind Singh Indraprastha University, New Delhi, India
}

Correspondence Author: Meghna Kaparwan, University School of Management Studies, Guru Gobind Singh Indraprastha University, New Delhi, India Received date: 11March 2019, Accepted date: 22 April 2019, Online date: 30 April 2019

Copyright: (c) 2019 Meghna Kaparwan, et al. This is an open-access article distributed under the terms of the Creative Commons Attribution License, which permits unrestricted use, distribution, and reproduction in any medium, provided the original author and source are credited.

\begin{abstract}
The present research was aimed to study the effect of consumer locus of control (CLOC) and product involvement ( high-involvement and low-involvement ) on the socially responsible behaviour of the consumer in order to determine whether the attention of the consumers towards the environmental and social issues is growing or not. A sample of 143 respondents was taken belonging to different sections of the society. Consumer Locus of Control Scale, Scale for Ecologically and Socially Conscious Consumer Behaviour and Involvement Scale were applied. The major results indicate that level of involvement effect ecologically conscious consumer behaviour while locus of control effect sociologically conscious consumer behaviour. The paper discusses various results in details.
\end{abstract}

Keywords: Consumer Locus of Control, Socially Responsible Behaviour, Economic Conditions

\section{INTRODUCTION}

Environmental sustainability and social responsibility are becoming major concerns when it comes to consumer buying behaviour. The world is facing numerous ethical and environmental issues. These issues are influencing the consumers in a way that they are trying to change their consumption pattern turning it to eco-friendly products. Socially and environmentally conscious consumer behaviour is essential in order to sensitise consumers about the need to switch to green products and services and also which are not causing any harm to society. There is a possibility that these practices might appear to be expensive in the short run, but these will have indispensable advantages in the long run and also with time these will become more cost-effective.

Every single time a consumer is making a decision regarding what to buy, he or she should realise the potential of their decision about how it can contribute to either a more or less sustainable pattern of consumption. Different individuals have different personalities and thus different perceptions about a common concern. Similarly, even while buying a particular product or service, some individuals can be impulsive and some can be strategic in their decision making. . The consumers' decision-making abilities can be determined by analysing their consumer locus of control. The measure of consumer locus of control is highly related to the consumer behaviour in a way that if an individual has an internal consumer locus of control then he or she will be more likely to take strategic decisions whereas if he or she will have an external locus of control they their decisions will not be as purposive.

The consumer locus of control helps to determine whether the consumers are ecologically and socially responsible or not while they are planning to purchase any good or service. There is a strong association between the internality of an individual and his inclination towards conservation policies regarding the environment and the society. The people with an internal locus of control strongly believe that they themselves are responsible for their own lives and thus pay more attention towards the protection of nature and toward the good of others living in the society. Thus their buying decisions are such that they try or make efforts to buy the products which are less harmful to the environment. Contrary to this the people with an external locus of control have thought that they have to plan their things according to the plans of others and thus have a perception that they do not have to care about these issues because other people are there who are thinking about it so they do not have to.

Being separate entities a dissimilar behaviour is shown by the consumers towards the product or service they intend to buy even after the socially responsible practices are adopted by the company but the case might not be the same when talking about the high involvement and low invol vement products. Thus this study is about how the consumer locus of control and product involvement has their effect on the socially responsible behaviour of the consumers.

\section{REVIEW OF LITERATURE}

Rahman [1] studied how the involvement of consumers affect their purchase intentions and their willingness to pay more. This study investigated whether the differences between high-involvement consumers and low-involvement consumers is significantly high for three green products which were green hotels, organic wine and green cars. The results of this study were such that they revealed that the extent of involvement which is associated with the product and the type of environment product strongly impact the buying intentions of the consumers. Thus, it is very important for marketers to design the campaign for green products accordingly. 
Dias [2] in a study stated that there is a direct and positive relationship between the consumer locus of control and their willingness to buy or recommend low complexity products. Thus the consumers with an internal locus of control are more likely to buy and recommend buying the low complexity products. On the other hand people with an external locus of control are less likely or not willing to buy or recommend buying low complexity co-created labelled products.

In their study of socially responsible consumer behaviour Kavran, Cerovic and Jelusic [3] stated that there are three dimensions of consumer social responsibility which are socially responsible investment, green products and good consumers. These dimensions helped to determine the relationship between the models of socially responsible consumers and how do they allocate their income. This study thus revealed that there is no positive relationship between the income of the consumers and their willingness to move their income for products coming from socially responsible companies.

A study by [4] stated that the dramatically growing attention of the consumers towards socially responsible practices may not show while they are buying the products which are at their purchase intention. Even though the consumers are becoming more responsible towards both the environment and the society they have a dissimilar attitude towards different products. This revealed that they do no show similar practices while buying high involvement and low involvement products.

[5] conducted a study which stated that the people with an internal locus of control support the conservation policies as they consider themselves responsible for their lives and thus think that they should protect nature. O the other hand the people with externality do not support the conservation policies because they do not consider themselves responsible for anything instead state other reasons responsible for the environmental issues.

\subsection{Objectives of the study}

\section{RESEARCH METHODOLOGY}

- To understand the relationship between consumer locus of control, ecologically and socially conscious consumer behaviour and involvement in the product without and with socio-eco- friendly information about the product.To understand the effect of consumer locus of control, involvement with the product with and without socio-eco- friendly information about the product on ecologically and socially conscious consumer behaviour. To understand the differences in ecologically and socially conscious consumer behaviour on the basis of types of consumer locus of control, level of involvement, and level of informed (socio-eco-friendly information) involvement

\subsection{Sample}

The sample consisted of 143 respondents (as shown in table 1) out of which 83 were males and 50 were females located in national capital region of Delhi. Out of 143 respondents 12 respondents belong to generation X, 73 belong to generation Y, and 58 belong to generation Z. as per the marital status 103 respondents were unmarried, 33 were married and 7 were divorced. Out of 143 respondents, 15 have their highest qualification less than graduation, 84 respondents were graduate, 38 were postgraduate and 6 respondents had the qualification more than post-graduation. As per the family income 27 respondents were having income 5 lac per annum, 31 respondents were having family income between 5 to 8 lacs, 46 respondents were having family income 8-12 lacs, 19 respondents were Having income 12-20 lacs and 20 respondents were having family income more than 20 lacs.

\subsection{Survey Instrument \\ Consumer locus of control}

The consumer locus of control scale was developed by [6]. It consists 14 items on 5 points Likert scale. Out of these 14 items, 8 items belong to external consumer locus of control and 6 items belong to internal consumer locus of control. The descriptions of the dimensions are given in table no 2 .

\section{Scale of ecologically and socially conscious consumer behaviour}

The ecologically and socially conscious consumer behaviour scale was developed by Robert in the year 1995. It consists of 24 items on 7 points Likert scale. Out of these 24 items, 17 items belong to ecologically conscious consumer behaviour and 7 items belong to socially conscious consumer behaviour. The descriptions of the dimensions are given in table 2 .

\section{Involvement scale}

The involvement scale was developed [7]. It consists of 10 items on 7 points semantic differential scale.

\subsection{Procedure}

The consumer locus of control and scale of socially conscious and ecologically conscious and ecologically conscious consumer behaviour was applied to all the respondents. To map the involvement and informed involvement the respondents were shown the advertisements of sports shoes at the first instance only with the information of the product and at the second instance additional information about eco and socio friendliness of the product. The respondents were asked to indicate their involvement with the product at both the instances

\section{RESULTS AND DISCUSSIONS}

Pearson's correlation was applied to understand the relationship between consumer locus of control, ecologically conscious consumer behaviour, socially conscious consumer behaviour, involvement, and informed involvement (as shown in table 3).

The results depicted that the ecologically conscious consumer behaviour has a significant positive relationship with involvement and informed involvement. Further, the result depicted that socially conscious consumer behaviour has significant positive relationship with informed involvement.As per the result involvement has a significant positive relationship with informed involvement and significant negative relationship with internal consumer locus of control. The results also depicts that informed involvement does not have any significant relationship with any of the factors considered for the study.

Linear regression analysis was applied to analyse the impact of consumer locus of control and involvement on ecologically conscious and socially conscious consumer behaviour and also the impact of consumer locus of control on involvement (as shown in Table 4). The results depicted that informed involvement has significant positive impact on ecologically conscious consumer behaviour up to an extent of $14.5 \%$. It means that when consumers were provided with the information about the product then they were more ecologically conscious about the product in general. The results further showed that informed involvement has significant positive impact on socially conscious consumer behaviour. Also, internal locus of control has significant positive impact on the socially conscious consumer behaviour which means that people with an internal locus of control are more socially conscious for products in general. Lastly, the internal locus of control has a significant negative impact on involvement which, means that people with an internal locus of control have lower involvement. This indicates that people with internal locus of control have personal preference for products but when they are p98rovided with pro-environment and pro-social information about the product then their involvement towards the product increases. The results also depicted that external locus of control does not have significant impact on either ecologically and social conscious consumer behaviour or on involvement.

Analysis of Variance was applied to understand the significant differences in the socially conscious consumer behaviour and ecologically conscious consumer behaviour of respondents with respect to their consumer locus of control, level of involvement and level of informed involvement. The results depict that respondents lying on different level of involvement differ significantly on their ecologically conscious consumer behaviour (Table 5). The scrutiny of Table 6 show that the respondents with high involvement are significantly higher on ecologically conscious consumer behaviour as compared to respondents on medium and low level of involvement, and respondents on medium level of involvement are significantly higher than low involvement respondents on ecologically conscious consumer behaviour. This means level of involvement determines ecologically conscious consumer behaviour.

The level of involvement was mapped after providing eco and socio friendly information about the product. Then the level of informed involvement was assessed. The results of analysis of variance (Table 5) show that respondents differ significantly on their ecologically and socially conscious consumer behaviour falling on different levels of informed involvement. The mean differences in Table 6 shows that respondents with high informed involvement are significantly 
higher on socially conscious consumer behaviour as compared to respondents with medium and low informed involvement. Further the mean scores reveal that the respondents with high, medium and low informed involvement differ significantly from each other on ecologically conscious consumer behaviour. This indicates that providing eco-friendly and socio-friendly information about the product can lead to higher ecologically and socially conscious consumer behaviour. The results also show that respondents with internal consumer locus of control are significantly higher than the respondents with external and equal consumer locus of control on their socially conscious consumer behaviour (Table 5, Table 6).

The involvement behaviour of the respondents was mapped first without providing eco and socio friendly information about the product and then planned again after providing eco and socio friendly information about the product. Interestingly the new eco and socio friendly information increased and decreased involvement of many respondents while in cases of many respondents the involvement level remained the same. The analysis of variance and table of means revealed that the socially conscious consumer behaviour was significantly higher of the respondents whose involvement increased after providing eco and socio friendly information about the product as compared to those respondents whose participation either decreased or remained unaffected after providing eco and socio friendly information about the product (Table 5, Table 6).

\section{Conclusion and Implications}

The ecologically and socially responsible behaviour is the need of the time if this planet and humanity have to be saved. Researchers are trying their part of the job to understand how these behaviours are governed and improved. The present study was attempted to understand the effect of consumer locus of control and involvement behaviour on ecologically and socially conscious behaviour. The results of the study show that informed involvement has a significant positive impact on environmentally conscious consumer behaviour and socially conscious consumer behaviour. Also, internal locus of control has significant positive impact on the socially conscious consumer behaviour. Respondents with high informed involvement were significantly higher on socially conscious consumer behaviour as compared to respondents with medium and low informed responsibility. The respondents with high, medium and low reported involvement differ significantly from each other on ecologically conscious consumer behaviour. This indicates that providing eco-friendly and socio-friendly information about the product can lead to higher environmentally and socially conscious consumer behaviour. The socially conscious consumer behaviour was significantly higher of the respondents whose involvement increased after providing eco and socio helpful information about the product as compared to those respondents whose involvement either decreased or remained unaffected after providing eco and socio helpful information about the product. The study provides a major insight that marketers must provide eco and socio-friendly details on the product so as to enhance sociologically and ecologically conscious behaviour.

\section{Limitation of the Study}

The study is limited to National Capital Region of Delhi. With sample size of 143, hence it cannot be generalised for rest of the region.

Table 1: Demographic Profile of respondents (143)

\begin{tabular}{|c|c|c|}
\hline \multirow{2}{*}{ Gender } & Male & 83 \\
\hline & Female & 50 \\
\hline \multirow{3}{*}{ Age Group } & Generation X & 12 \\
\hline & Generation Y & 73 \\
\hline & Generation Z & 58 \\
\hline \multirow{3}{*}{ Marital Status } & Unmarried & 103 \\
\hline & Married & 33 \\
\hline & Divorced & 7 \\
\hline \multirow{4}{*}{ Education } & Less than Graduation & 15 \\
\hline & Graduation & 84 \\
\hline & Post-Graduation & 38 \\
\hline & More than Post-Graduation & 6 \\
\hline \multirow{5}{*}{ Household Income } & $0-5$ lacs & 27 \\
\hline & 5-8 lacs & 31 \\
\hline & 8-12 lacs & 46 \\
\hline & 12-20 lacs & 19 \\
\hline & More than 20 lacs & 20 \\
\hline
\end{tabular}

Table 2: Table showing the factors and their explanation used for the study

\begin{tabular}{|c|c|c|}
\hline S. No & Variables & Explanation \\
\hline 1 & Internal consumer locus of control (ICLOC) & $\begin{array}{c}\text { Consumers who base their choices and preferences on their own beliefs have an } \\
\text { Internal consumer locus of control. This category of consumers first assesses } \\
\text { the product and if satisfied with the same, goes for buying it. }\end{array}$ \\
\hline 2 & External consumer locus of control (ECLOC) & $\begin{array}{c}\text { The consumers who are influenced by external factors and buy the product, but } \\
\text { if not satisfied with the same, they try to rationalize their judgment. } \\
\text { While making a purchase, if a consumer buys a product which is not } \\
\text { ecologically harmful to the environment, then this buying behavior will be } \\
\text { termed as ecologically conscious consumer behavior. }\end{array}$ \\
\hline 4 & $\begin{array}{c}\text { Ecologically conscious consumer behavior } \\
\text { (ECCB) }\end{array}$ & $\begin{array}{c}\text { While making a purchase, if a consumer buys a product which is not hurting } \\
\text { the sentiments of the society in any form, then this buying behavior will be } \\
\text { termed as Socially conscious consumer behavior. }\end{array}$ \\
\hline 5 & Socially conscious consumer behavior (SCCB) & $\begin{array}{c}\text { Involvement means that a product is important, needed, means a lot, involving, } \\
\text { valuable, exciting, appealing, fascinating, interesting and relevant. }\end{array}$ \\
\hline 6 & Involvement & $\begin{array}{c}\text { Informed involvement means When eco and socio friendly information is } \\
\text { provided about the product then the product becomes important, needed, means } \\
\text { a lot, involving, valuable, exciting, appealing, fascinating, interesting and } \\
\text { relevant. }\end{array}$ \\
\hline
\end{tabular}


Citation: Meghna Kaparwan, 2019. Impact of Consumer Locus of Control and Involvement on Socially and Ecologically Conscious Consumer Behaviour. Journal of Applied Sciences Research., 15(2): 5-9. DOI: 10.22587/jasr.2019.15.2.2

Table 3: Showing Correlations of Consumer Locus of Control, Ecologically Conscious Consumer Behaviour, Socially Conscious Consumer Behaviour, Involvement and Informed Involvement.

\begin{tabular}{|c|c|c|c|c|}
\hline & $\begin{array}{c}\text { External } \\
\text { Consumer } \\
\text { Locus of } \\
\text { Control } \\
\end{array}$ & $\begin{array}{c}\text { Internal } \\
\text { Consumer } \\
\text { Locus of } \\
\text { Control } \\
\end{array}$ & Involvement & Informed Involvement \\
\hline $\begin{array}{c}\text { Ecologically Conscious Consumer } \\
\text { Behaviour }\end{array}$ & .024 & .076 & $.215^{* *} *$ & $.381 * *$ \\
\hline $\begin{array}{l}\text { Socially Conscious Consumer } \\
\text { Behaviour }\end{array}$ & -.033 & $.344 * *$ & -.012 & $.252 * *$ \\
\hline Involvement & -.014 & $-.176^{*}$ & ----- & $.218 * *$ \\
\hline Informed Involvement & .007 & .052 & -------- & -------------- \\
\hline \multicolumn{5}{|c|}{$\begin{array}{l}* \text { * Correlation is significant at the } 0.05 \text { level (2-tailed). } \\
* * \text {. Correlation is significant at the } 0.01 \text { level (2-tailed). }\end{array}$} \\
\hline
\end{tabular}

Table 4: Regression analysis of consumer locus of control and involvement on ecologically conscious and socially conscious consumer behavior

\begin{tabular}{|c|c|c|c|c|c|c|c|c|}
\hline \multirow[t]{2}{*}{ Predictors } & \multirow{2}{*}{ F (sig) } & \multirow{2}{*}{$\mathbf{R}^{2}$} & \multirow{2}{*}{ Adjusted $\mathbf{R}^{2}$} & \multicolumn{2}{|c|}{$\begin{array}{c}\text { Un standardized } \\
\text { Coefficients }\end{array}$} & \multirow{2}{*}{$\begin{array}{c}\begin{array}{c}\text { Standardized } \\
\text { Coefficients }\end{array} \\
\text { Beta }\end{array}$} & \multirow{2}{*}{$\mathbf{t}$} & \multirow{2}{*}{ Sig. } \\
\hline & & & & B & $\begin{array}{c}\text { Std. } \\
\text { Error }\end{array}$ & & & \\
\hline \multicolumn{9}{|c|}{ Dependent Variable: Ecologically Conscious Consumer Behaviour } \\
\hline $\begin{array}{c}\text { Informed } \\
\text { Involvement }\end{array}$ & $\begin{array}{l}23.912 \\
(.000)\end{array}$ & 0.145 & 0.139 &. .626 & .128 & .381 & 4.890 & .000 \\
\hline \multicolumn{9}{|c|}{ Dependent Variable: Socially Conscious Consumer Behaviour } \\
\hline $\begin{array}{c}\text { Internal } \\
\text { Consumer Locus } \\
\text { of Control }\end{array}$ & \multirow{2}{*}{$\begin{array}{l}14.67 \\
(.000)\end{array}$} & \multirow[t]{2}{*}{.173} & \multirow[t]{2}{*}{.161} & .921 & .213 & .332 & 4.315 & .000 \\
\hline $\begin{array}{c}\text { Informed } \\
\text { Involvement }\end{array}$ & & & & .202 & .066 & .234 & 3.047 & .003 \\
\hline \multicolumn{9}{|c|}{ Dependent Variable: Involvement } \\
\hline $\begin{array}{c}\text { Internal } \\
\text { Consumer Locus } \\
\text { of Control }\end{array}$ & $\begin{array}{c}4.51 \\
(.035)\end{array}$ & .031 & .024 & -.631 & .297 & -.176 & -2.125 & .035 \\
\hline
\end{tabular}

Table 5: Showing Analysis of Variance of Various Independent Variables on Socially and Ecologically Conscious Consumer Behaviour

\begin{tabular}{|c|c|c|c|c|c|c|}
\hline Independent Variable & Dependent Variable & $\begin{array}{l}\text { Type III Sum of } \\
\text { Squares }\end{array}$ & df & $\begin{array}{c}\text { Mean } \\
\text { Square }\end{array}$ & $\mathbf{F}$ & Sig. \\
\hline Level of Involvement & $\begin{array}{c}\text { Ecologically Conscious Consumer } \\
\text { Behaviour }\end{array}$ & 3567.26 & 2 & 1783.63 & 6.94 & .001 \\
\hline \multirow{2}{*}{ Level of Informed Involvement } & $\begin{array}{c}\text { Socially Conscious Consumer } \\
\text { Behaviour }\end{array}$ & 8055.00 & 2 & 4027.50 & 17.90 & .000 \\
\hline & $\begin{array}{c}\text { Ecologically Conscious Consumer } \\
\text { Behaviour }\end{array}$ & 1422.44 & 2 & 711.22 & 10.62 & .000 \\
\hline $\begin{array}{l}\text { Type of Consumer Locus of } \\
\text { Control }\end{array}$ & $\begin{array}{c}\text { Socially Conscious Consumer } \\
\text { Behaviour }\end{array}$ & 927.82 & 2 & 463.91 & 6.72 & .000 \\
\hline $\begin{array}{l}\text { Effect of Providing Ecological and } \\
\text { Social friendly Information about } \\
\text { the product }\end{array}$ & $\begin{array}{c}\text { Socially Conscious Consumer } \\
\text { Behaviour }\end{array}$ & 1256.42 & 2 & 628.21 & 9.213 & .000 \\
\hline
\end{tabular}

Note: Only Significant Results are shown

Table 6: Showing Significant Mean Differences of Various Independent Variables on Socially and Ecologically Conscious Consumer Behaviour

\begin{tabular}{|c|c|c|c|c|}
\hline Independent Variable & Level of Involvement & Low Involvement & $\begin{array}{c}\text { Medium } \\
\text { Involvement }\end{array}$ & High Involvement \\
\hline Dependent Variable & $\begin{array}{l}\text { Ecologically Conscious } \\
\text { Consumer Behaviour }\end{array}$ & 56 a & $65.74_{b}$ & $74.26_{\mathrm{c}}$ \\
\hline Independent Variable & Level of Informed Involvement & Low Involvement & $\begin{array}{c}\text { Medium } \\
\text { Involvement }\end{array}$ & High Involvement \\
\hline \multirow{2}{*}{ Dependent Variable } & $\begin{array}{l}\text { Socially Conscious Consumer } \\
\text { Behaviour }\end{array}$ & $31.6_{\mathrm{a}}$ & $31.35_{\mathrm{a}}$ & $40.28 \mathrm{~b}$ \\
\hline & $\begin{array}{l}\text { Ecologically Conscious } \\
\text { Consumer Behaviour }\end{array}$ & $48.5_{\mathrm{a}}$ & $64.42_{b}$ & $81.0_{\mathrm{c}}$ \\
\hline Independent Variable & Consumer Locus of Control & $\begin{array}{l}\text { Equal Consumer } \\
\text { Locus of Control }\end{array}$ & $\begin{array}{c}\text { External } \\
\text { Consumer Locus } \\
\text { of Control }\end{array}$ & $\begin{array}{l}\text { Internal Consumer } \\
\text { Locus of Control }\end{array}$ \\
\hline Dependent Variable & $\begin{array}{l}\text { Socially Conscious Consumer } \\
\text { Behaviour }\end{array}$ & $31.04_{\mathrm{a}}$ & $31.56_{\mathrm{a}}$ & $34.20_{\mathrm{b}}$ \\
\hline Independent Variable & $\begin{array}{l}\text { Effect of Providing Ecological } \\
\text { and Social friendly Information } \\
\text { about the product }\end{array}$ & No Effect & $\begin{array}{l}\text { Decreased } \\
\text { Involvement }\end{array}$ & Increased Involvement \\
\hline \multirow[t]{2}{*}{ Dependent Variable } & $\begin{array}{c}\text { Socially Conscious Consumer } \\
\text { Behaviour }\end{array}$ & $31.15_{\mathrm{a}}$ & $34.28_{\mathrm{a}}$ & $39.47_{\mathrm{b}}$ \\
\hline & \multicolumn{4}{|c|}{$\begin{array}{l}\text { Note: Means with differing subscripts within rows are significantly different at the } \mathrm{p}<.05 \text { based on } \\
\text { Duncan Multiple Range post hoc paired comparisons. }\end{array}$} \\
\hline
\end{tabular}


Citation: Meghna Kaparwan, 2019. Impact of Consumer Locus of Control and Involvement on Socially and Ecologically Conscious Consumer Behaviour. Journal of Applied Sciences Research., 15(2): 5-9. DOI: 10.22587/jasr.2019.15.2.2

[1] Citation Missing

\section{REFERENCES}

[2] Dias AAGR, Locus of control effect in the purchase and recommendation decision of Co-created labeled product. Universidade Catolica Portuguesa.2016.Unpublished Thesis

[3] Kavran AK, Cerovic L. Socially Responsible Consumer Behavior.2015

[4] Emadi MS. The effect of product involvement on socially responsible consumer behavior. University of Missouri.2013.Unpublished thesis

[5] Citation Missing

[6] Busseri MA, Lefcourt HM, Kerton RR.Locus of control for consumer Outcomes: Predicting Consumer Behaviour.Journal of Applied Social Psychology.1998:28(12):1067-1087

[7] Zaichkowsky, J. L. (1994). the personal involvement inventory: reduction, revision, and application to advertising. Journal of Advertising, 59-70.

[8] Lakra P, Bedi P, Gupta E. Consumer behavior with reference to green consumption and sustainability. International Research Journal of Management Science \& Technology. 2014:5(4):4-11

[9] Ilie MP, Unianu EM. Locus of control and the pro-environmental attitudes. Procedia - Social and Behavioral Science. 2012:33:198-202

[10] Roberts, J. A. (1995). Profiling levels of socially responsible onsumer behavior: A cluster analytic approach and its implications for marketing. Journal of marketing theory and practice, $97-117$. 